\title{
State of Apparent Death and Origin of Dreams: A Historical Review of German Literature of the 19th and Early 20th Centuries
}

\author{
Birk Engmann, Dr. med. \\ Brandis, Germany
}

\begin{abstract}
In this article I review the German literature of the 19th and early 20th centuries that addressed two phenomena: the state of apparent death and the origin of dreams. Because the term near-death experiences (NDEs) did not yet exist, many features of those phenomena as they are currently understood were subsumed under the broad concept of the state of apparent death, whereas early theories of the origin of dreams included spiritual views that have similarities to current views of NDEs.
\end{abstract}

KEY WORDS: near-death experiences, state of apparent death, dream

Reports about the state of apparent death-a state in which life seems to be extinguished but in reality is not fully extinguished (Meyers Konversations-Lexikon 1897) — have a long tradition in European philosophy and science. Plato (about 424/423-348/347 BC) and Demokritus (about 460-370 BC), for instance, delivered such stories to posterity. In his Natural History, Pliny the Elder (23-79 AD) wrote about a consul who had been declared dead but woke up during cremation and eventually died (Plinius Secundus, c. 77-79 AD/1994). On the one hand, such stories reinforced spiritual views; on the other hand, they reinforced fears of being buried alive. As a consequence of the latter, many authors from the turn of the 18th through the 19th centuries dealt with the problem of apparent death and suggested several meth-

Birk Engmann, Dr. med., is in the department of neurology at Fachklinikum Brandis. Correspondence regarding the article should be sent to Dr. Engmann at Fachklinikum Brandis, Am Wald, D-04821 Brandis, Germany or to email: oa.engmann@ fachklinikum-brandis.de. 
ods and devices to detect it so as to prevent premature burial. Along with attention to those fears were observations about the state of apparent death itself and theories that arose from those observations.

Another focus in the literature of this era that has relevance to the field of near-death studies is the literature about theories of the origin of dreams. During this time, dreams and death were based on common concepts. Philosopher, theologian, and poet Johann Gottfried Herder (1744-1803), for example, referred to death as an ongoing sleep in his poem Schlaf und Tod-ein Abendsegen (Sleep and Death-An Evening Prayer; Herder, 1836).

The 19th century is rightly considered as being revolutionary in view of the enormous efforts in science. Beginning with the Age of Enlightenment, religious dogma and traditional views were disputed frankly. Within this cultural dialog, both of the aforementioned topics, the state of apparent death and the origin of dreams, attracted wide interest. Early 19th century concepts of spiritual phenomena were influenced by romantic philosophy. This branch of philosophy in Germany is regarded as an opposite direction to Immanuel Kant's (1724 Königsberg -1804 Königsberg) rationalism. It was, as Hans Joachim Störig (b.1915) put it, an "appeal on non-rational, emotional powers of man and the world" (p. 374). So, among other things, Kant (1790/1922) argued against the possibility of a proof of the existence of the supernatural. In addition, romantic philosophy itself was influenced by concepts of vital energy or animal magnetism, whereas the latter had also been included in the concept of (luminiferous) ether. Those concepts postulated energetic media that could function as carrier spirits but were also used for explanation of phenomena like somnambulism or, in physics, the propagation of light.

To trace the relative development of the threads of romantic and rationalist philosophies through 19th and early 20th century German literature as they relate to the topics of the state of apparent death and the origins of dreams, I here present representative examples of both the scientific and popular scientific literature. I used the advanced search engine Karlsruher Virtueller Katalog that catalogues 500 million volumes from German and worldwide libraries. In addition, I used advanced search engines of the German National Library and the University Library of Leipzig as well as references in books. My search criteria were: apparent death and dream. Following is a discussion of the literature I found and the trends with regard to philosophical perspectives. 


\section{9th and Early 20th Century German Literature on Apparent Death and the Origin of Dreams}

As mentioned above, the turn of the 19th century was accompanied by an increase in literature of apparent death, mostly dealing with fears of premature burial. An outstanding German publication at that time was Der Scheintod (State of Apparent Death) by physician Christoph Willhelm Hufeland (1762-1836), published in 1808. It became a very popular book that can be regarded as an encyclopedic work about the whole field of apparent death.

In 1822, Thuringian general practitioner Karl Ludwig Kaiser (biographical data unknown) published a book, the title of which translates to "on death and apparent death and the danger of early burying" (Über Tod und Scheintod oder die Gefahren des frühen Begrabens). He defined the state of apparent death as the highest degree of fainting, from which only the true sign of death-rot-is missing. He also noted that sometimes persons with "apparent death have a full consciousness, hear and feel everything, but cannot spout off the slightest sign of life" (p. 39). But he let the matter rest and said that a last spark of life is still present that could flare up again when the person regains life. He named various causes of apparent death, such as anemia, cold, drowning, or drugs.

Jena-born philosopher Immanuel Hermann Fichte (1796-1879), son of the philosopher Johann Gottlieb Fichte (1762-1814), published a famous book about the human soul. He also criticized Kant's abovementioned opinion vigorously (Fichte, 1856, p. 339, §139). Immanuel Fichte wrote, "there are states of consciousness of the soul which appear independently from organic apparatus of body and its requirements and thus show a non-fixed consciousness" (Fichte, 1856, p. 398, $\S 166)$. Furthermore, he declared the liberation of a "primordial ability" and a mental "primitive state" (p. 396, §165). Along these lines, Fichte made reference to continuity of mind before birth and after death and thus a linkage to a "golden age" of primeval times. So it is not surprising that Fichte pointed out reports of mentally ill people who became very clear in mind shortly before death ("spirit loses inhibitions," p. 394); thus, his positive attitude towards clairvoyance is understandable. For his arguments, Fichte searched for support and proofs in the physics of his time by using concept of luminiferous ether and declared spirit as one of its various energies. According to him, after death a person is just a spirit without a hull. This concept of eter- 
nal soul or spirit he also used to discuss the origin of dreams, which are a "sensation from outside which arouses the soul on behalf of the brain" (p. 405, §169). For proof of his argument, Fichte used examples such as somnambulism, psychic sensations caused by opium consumption, cannabis, monkshood (aconitum) intoxication, and the case of a girl who toppled and became unconsciousness. All cases shared "an intensive and extensive enhancement of consciousness" (p. 406, §170).

Another remarkable work on dreams derives from the philosopher, physician, and natural scientist Gotthilf Heinrich von Schubert (1780-1860). Like many scientists of his decade, he tried to combine scientific knowledge with the Bible. In his 1814 book Die Symbolik des Traumes (Symbolism of Dreams) he introduced a dualistic system of a ganglia system and its counterpart cerebral system. Whereas the first is regarded as the origin of emotions, the latter is the location of consciousness, of the sense of sight, and of hearing. He postulated a "partition wall" between them. During sleep, state of apparent death, or similar cases, he wrote, the partition has disappeared which causes feelings of complacency and blessedness. Dreams have a primordial language. This language is love, and love is divine, a language that once existed between God and humans (pp. 148-9).

In 1846, the famous German physician and painter Carl Gustav Carus (1789 Leipzig-1869 Dresden) published an influential book with the title Psyche. Zur Entwicklungsgeschichte der Seele (Psyche. The Historical Development of Soul; as far as I know (AFAIK), no English translation). He still held a spiritual interpretation of dreams. Indeed, Carus (1846/1930) mainly introduced the term subconsciousness into science, a conceptualization that comes from the mathematician and philosopher Gottfried Wilhelm Leibniz (1646 Leipzig-1716 Hanover) and that, half a century after Carus, became essential for psychoanalytic concepts. Carus argued that subconsciousness dominates the state of dreaming which "binds the dreamer closer to general life of the world, which universalizes the person, and that's why the dreamer is pervaded by all motions of the world" (p. 216). Hence, even "past and future and time in general interpenetrate and encounter" (p. 216). By contrast, he related individuality, character, and freedom to waking consciousness. So Carus accepted and justified divination in dreams (Carus, 1846/1930, p. 216). This view also appeared in later works on dreams, such as Johannes Volkelt's (1848-1930) in 1875: Dreams are a reflection of the eternal, perpetual great movement of the world (Volkelt, 1875/2005).

Konrad Martin (1812-1879), professor of theology at the University 
of Bonn, published his Lehrbuch der katholischen Moral (Textbook of Catholic Morality) in 1855. He strictly abandoned any dream interpretation and divination because, he asserted, it happens with "explicit appeal of the devil” (p. 596, §254).

At the same the time, philosopher Ludwig von Strümpell (1812 Schöppenstedt - 1899 Leipzig) published in 1868 a script about dreams that, a few years later, was published as a book. It was one of the works that made a deep impression on Sigmund Freud (1856 Freiberg/Příbor -1939 London) as reflected in his seminal book The Interpretation of Dreams (1900/1913). Strümpell did not follow spiritualist views and postulated the dream as a continuum of waking consciousness. In the following years other researchers, such as W. Robert (no biographical data known) in an 1886 work, positioned themselves against supernatural speculations (Robert, 1886/2005), whereas Friedrich Scholz (1831-1907) postulated that whatever the dreamer dreams originates from things he had already once experienced in daily life (Scholz, 1886/2005) - a concept that also influenced Freud.

In 1866, Franz Splittgerber (dates of birth and death unknown), a royal Prussian preacher of garrison Kolberg (Kołobrzeg), published a comprehensive and remarkable book about sleep and death. More directly than Carus he postulated an "intense enhancement of life of soul during a dream ... up to its highest peak; hitherto where dreams become a medium of a divine revelation" (Splittgerber, 1866, p. 160).

Splittgerber's (1866) book Schlaf und Tod (Sleep and Death; AFAIK no English translation) is also worth reading with regard to near-death experiences (NDEs). In those times, such experiences were subsumed under the state of apparent death. On the basis of a dualism of body and soul, Splittgerber explained the state of apparent death as follows:

Either in such cases the body possesses still enough life forces to keep the escaping ruler (i.e. the soul) and to bind her to her structured organism for a longer or shorter time; or the soul hasn't fulfilled her tasks in this world yet and therefore turns back to terrestrial life; or she isn't prepared yet for reprieve in this world in order to appear in front of judgement seat of the lively God. (p. 304)

The author also recognized differences in frequency of reports about such experiences. In women, he claimed, the "band between body and soul . . . is more loose, but in the same measure more elastic," which is why more women than men suffer from "syncope, catalepsy, magnetic sleep and apparent death" (Splittgerber, 1866, p. 307). 
Following on this point, Splittgerber (1866) focused on typical experiences of persons who survived a state of apparent death. He mentioned noises, such as the sound of bells, a noisy river, or the pitching of rods of helpers reported by a man who broke through the ice. According to Splittgerber, others described "overwhelming, sweet feelings" or reported about a "wonderful location" where they "saw several of their deceased relatives": "Everything is so nice and delightful there" (pp. 317-318). He also cited cases involving a "prophetic talent" (p. 319), feelings of fear, visual phenomena (seeing a white garment), or a "panorama view" of life in which memories of life events occur in rapid succession (p. 354). He described a "distant view" (p. 385), referring to people who reported that they knew exactly what happened in distant locations where they had never been before. Furthermore, "doppelgänger" (p. 387) reports were mentioned, that is, seeing oneself from distant positions, a term that, today, could refer to out-of-body experiences or autoscopy. It is remarkable that Splittgerber revealed a variety of triggers for such experiences, including breaking through the ice, "death-like stiffness" (p. 313), and "frail farmer's boy with aching disease" (p. 313). Amazingly, the author regarded such discrepancies critically. He asked himself if such experiences or reports should be considered as "conceited creations of an excited and mentally ill fantasy" (p. 337) or as "impartial truthes which give us an immediate insight in things and processes of an otherworld" (p. 337). He answered the questions that he "wouldn't admit either alternative, but would instead seek the truth in the middle" (p. 337). His argument was that experiences in the state of apparent death are too different. "The visions report about otherworld and the elevating and harrowing events in suchlike pictures and symbols which the person also has when awake. With other words: exactly from that religious view a person also has in ordinary life" (pp. 337-338). If one strips off the "subjective and fantastic garment" (p. 339) of the experiences, then they "harmonize with the religious basic views of God's word, that after them a retributive justice rules in the afterworld" (p. 339). Splittgerber pleaded for a personal god and against pantheist theories that were very popular in his time.

At nearly the same time that Splittgerber's book was published, a German translation from an 1861 Dutch edition appeared on the book market. Dutch physician Alexander Willem Michiel van Hasselt (1814-1902) published a short compendium about death and apparent death that could be regarded as a precursor of modern thanatology. Van Hasselt (1862) defined apparent death as "a state of animal or- 
ganism, in which life hasn't completely ceased yet and in which life could get back into efficacy under favourable circumstances" (p. 84). He underlined that apparent death "does not proclaim itself to the outside by sensory perceptible appearances" (p. 84). It is noteworthy that, in this formulation, van Hasselt indicated indirectly the lack of methods to prove an apparent death and, furthermore, gave a general definition for animal life that included human beings as well-two years after Charles Darwin's (1859) influential book On the Origin of Species! Van Hasselt discriminated different causes of apparent death such as asphyxia, stroke, heart attack, intoxication, heat, cold, heat, described symptoms as headache, vision of sparks, visual and auditory hallucinations, and feelings of anxiety that could appear afterwards. Concerning cases in which people reported things they might really have heard after apparent death, he reasoned that in apparent death life is not completely extinguished but rather is reduced to a minimum. Additionally, van Hasselt's book is important for detailed discussion about several reports of reanimation.

Almost 120 years ago, a dispute started between influential Leipzig physician Paul Möbius (1853-1907) and the Austrian physician and later Nobel Prize winner Julius Wagner-Jauregg (1857-1940). They debated in influential German and Austrian medical journals about interpretation of physical and psychic phenomena of persons who had been reanimated successfully after strangulation. They referred to phenomena such as seizure-like conditions, retrograde amnesia, and "muzziness and illusions" (Wagner-Jauregg, 1889, p. 323) associated with the time of reanimation. Möbius (1893) explained such symptoms as originating from a traumatic reaction, which is similar to the current notion of posttraumatic stress disorder. Wagner-Jauregg (1893) emphasized "asphyxia" and obturation of carotid arteries as the main cause. Möbius (1893) reproached Wagner-Jauregg for being a psychiatrist who "wants to interpret everything in a physiological way" ( $p$. 128). Wagner-Jauregg (1893) replied that "neglecting all experimental results, especially those of animal experiments" does not indicate impartiality of the clinician but rather the "impartiality of inexperience" (p. 194).

Coincidentally, Swiss geologist Albert Heim (1849-1937) published a paper in which he described reports from wounded soldiers but more detailed reports from mountaineers who had once fallen but survived. He described feelings of those people just at the moment they lost consciousness and reported, for example, absence of pain, a clear mind, and a review of one's own biographical history. "At least the plunging 
person often hears nice music and then falls into a wonderful blue sky with pink clouds" (p. 329). As a person who wanted to avoid either "physiological" or "philosophical" explanations, his observations were evidence that death mostly appears with comfort. Death by fall is a "nice death" (p. 336). But it is apparent that Heim mostly quoted stories of dangerous, life-threatening situations or severe injuries rather than cases of apparent death.

Wilhelm Ebstein (1836 Jauer/Jawor - 1912 Göttingen), professor of internal medicine whose name is eponym of many diagnoses, investigated medical reports in the Old Testament of the Bible. In 1901 his popular book Die Medizin im alten Testament (Medicine in the Old Testament; AFAIK no English translation) was published. Ebstein (1901/2008) also reported about the state of apparent death in texts of the Bible and gave physiological explanations such as sunstroke.

The influential German encyclopedia Meyers Konversations-Lexikon (1897) also provided its readers with physiological explanation of some peculiarities of apparent death. These included persistence of audition and consciousness during apparent death.

At nearly the same time, in 1907, a popular scientific brochure about the secrets of death was published. Presumably this brochure was a revised and updated edition of a book from the mid-1850s edited by the Leipzig-born physician and popular scientific writer Gottfried Wilhelm Becker (1778-1854). Contrary to its mystic title, Die Geheimnisse des Todes (Mysteries of Death; no English ed.), the 1907 edition is based on rational views. The author quoted case histories from people who survived a state of apparent death and reported experiences like reviewing their own lives as well as "revival of completely forgotten language abilities" (Becker, 1907, p. 65). He also argued that those experiences weren't an "increase of mental abilities . . . but rather their decrease" (p. 66). He attributed "irritations which are followed by a depression of the nerves" to lack of oxygen. This "depression" would be accompanied by a "mental excitement with delirium and hallucinations" (pp. 66-67).

About 15 years later, in 1923, an internist who was head and owner of a hospital in Silesian Ober-Schreiberhau (Szklarska Poręba), Johannes Haedicke, published the book Über Scheintod, Leben und Tod (About Apparent Death, Life and Death; no English ed.). It is noteworthy that he offered the following definition: "The state of apparent death is a state in which life as a whole is annihilated caused by change of existential conditions but which can recover by renewal of vital activity of those existential conditions" (p. 288). 
At almost the same time, French-German couple Cécile Vogt (18751962) and Oskar Vogt (1870-1959) published their research findings about "pathoclisis," which means a different inclination of various organs and, again, a different inclination of various tissues within those organs, to poisons, lack of oxygen, or disturbance of blood supply to develop pathological changes. The authors argued in this vein:

We want to draw attention to the point that psychic disturbances which we observe in normal people at the end of a lethal disease or in agony are ascribed not only to circulatory disturbances in the brain but to changes of cerebral parenchyma. It is important to analyse psychic behaviour of dying people more precisely and relate this to cerebral changes in order to elucidate pathophysiology of premortal psychic symptoms, which also are important for psychiatry. (p. 165)

This is a model that I prefer for the explanation of NDE after a survived clinical death (Engmann, 2011).

\section{Summary}

Concepts of the origin of dreams and apparent death were influenced by romantic types of philosophy and its affiliated concepts such as ether, animal magnetism, or vital energy. Theorists postulated a continuity of the soul stretching from time before birth to time after death. They believed life represents the period in which soul is bounded and/or inhibited by the human body. In some circumstances, such as dreams, apparent death, or shortly before final death, the soul is liberated and gets touched with primordial language or primitive states. Such views sound like a "myth of paradise" (Eliade, 1961/1967), a fortunate primal state.

Simultaneously, some theorists developed rational concepts of the origin of dreams and apparent death. In the course of time such concepts that treated experiences in dreams and apparent death as physiological phenomena prevailed more and more, especially in the scientific literature.

But it is notable that even protagonists of spiritual views, such as Splittgerber (1866), mentioned essential problems in apparent death reports, such as multiple realizations of mental states and the influence of personal religious views. His implication was that different causes could provoke the same mental experiences. This view is an anticipation of present-day discussions of NDEs. Even spiritual concepts of dreams and the state of apparent death endured over decades until today. So it seems that the current term NDEs includes much 
of the spiritual "function" that dreams and apparent death once had. Today it is NDEs that offer gnostic knowledge of meeting with God or a proof of the existence of an immortal soul. Even clairvoyant abilities in NDEs are reported.

All in all, many points of current discussions on NDEs reflect topics already evident in the German literature from the past two hundred years. The professional debates of today are echoes of those put forth many decades ago.

\section{References}

Becker, G. W. (1907). Die Geheimnisse des Todes [Mysteries of death]. Leipzig, Germany: Verlag Fritzsche und Schmidt.

Carus, C. G. (1930). Psyche. Zur Entwicklungsgeschichte der Seele [Psyche. The historical development of soul]. Leipzig, Germany: Alfred-Kröner-Verlag. (Original work published 1846)

Darwin, C. (1859). On the origin of species. London, England: John Murray.

Ebstein, W. (2008). Die Medizin im Alten Testament [Medicine in the Old Testament]. Saarbrücken. Germany: VDM Verlag Dr. Müller. (Original work published 1901)

Eliade, M. (1967). Myths, dreams, and mysteries: The encounter between contemporary faiths and archaic realities (p. Mairet, Trans.). New York, NY: Harper \& Row. (Original work published 1961)

Engmann, B. (2011). Mythos Nahtoderfahrung [The myth of near-death experience]. Stuttgart, Germany: Hirzel.

Fichte, I. H. (1856). Anthropologie. Die Lehre von der menschlichen Seele [Anthropology. The doctrine of human soul]. Leipzig, Germany: F. A. Brockhaus.

Freud, S. (1913). The interpretation of dreams. (A. A. Brill, Trans). New York, NY: Macmillan. (Original work published 1900)

Haedicke, J. (1923). Über Scheintod, Leben und Tod. Ein Beitrag zur Lehre von dem Leben und der Wiederbelebung [About the state of apparent death, life and death]. Ober-Schreiberhau, Silesia, Germany (present-day Poland): Kultur und Gesundheit.

Heim, A. (1892). Notizen über den Tod durch Absturz [Remarks on fatal falls]. Jahrbuch des Schweizer Alpenclub [Yearbook of the Swiss Alpine Club], 27, 327-337. (English trans.: Noyes, R., \& Kletti, R. [1972]. The experience of dying from falls. Omega, 3, 45-52.)

Herder, J. G. (1836). Schlaf und Tod-ein Abendsegen [Sleep and Death-An Evening Prayer]. In J. G. Müller (Ed.), Gedichte [Poems] (vol. 2, Jugendgedichte [Youth poems]; pp. 95-96). Stuttgart und Tübingen, Germany: Cotta'sche Buchhandlung.

Hufeland, C. W. (1808). Der Scheintod [State of apparent death]. Berlin, Germany: Matzdorf.

Kaiser, K. L. (1822). Über Tod und Scheintod oder die Gefahr des frühen Begrabens [On death and apparent death or danger of early burying]. Frankfurt am Main, Germany: Jäger'sche Buch-, Papier- und Landkartenhandlung. 
Kant, I. (1922). Kritik der Urteilskraft [Critique of judgment]. Leipzig, Germany: Verlag von Felix Meiner. (Original work published 1790)

Martin, K. (1855). Lehrbuch der katholischen Moral [Textbook of catholic morality] Mainz, Germany: Verlag von Franz Kirchheim.

Meyers Konversations-Lexikon [Meyer's encyclopedia]. (1897). Volume 15. Leipzig, Germany and Wien, Austria: Bibliographisches Institut.

Möbius, P. J. (1893). Bemerkungen zu dem Aufsatze Prof. Wagner's "Ueber Krämpfe und Amnesie nach Wiederbelebung Erhängter" [Remarks on Professor Wagner's essay "About cramps and amnesia after reanimation of strangulated persons"]. Münchner Medicinische Wochenschrift, 40, 127-129.

Plinius Secundus, G. (1994). Naturkunde [natural history], VII, 52. Zürich, Switzerland: Artemis und Winkler. (Original work published c. 77-79 AD).

Robert, W. (2005). Der Traum als Naturnothwendigkeit erklärt [Dream as a necessity]. In S. Goldmann (Ed.), Traumarbeit vor Freud. Quellentexte zur Traumpsychologie im späten 19. Jahrhundert (Dreamwork before Freud; pp. 291-318). Gießen, Germany: Psychosozial-Verlag. (Original work published 1886)

Scholz, F. (2005). Schlaf und Traum. Eine populärwissenschaftliche Darstellung [Sleep and dream. A popular scientific description]. In S. Goldmann (Ed.), Traumarbeit vor Freud. Quellentexte zur Traumpsychologie im späten 19. Jahrhundert (Dreamwork before Freud; pp. 319-348). Gießen, Germany: Psychosozial-Verlag. (Original work published 1886)

Splittgerber, F. (1866). Schlaf und Tod [Sleep and death]. Halle/Saale, Germany: Verlag von Julius Fricke.

Störig, H. J. (1958). Kleine Weltgeschichte der Philosophie [Brief history of philosophy]. Stuttgart, Germany; Zürich, Switzerland; and Salzburg, Austria: Europäischer Buchklub.

Strümpell, L. (2005). Die Natur und Entstehung der Träume. [Nature and origin of dreams]. In S. Goldmann (Ed.), Traumarbeit vor Freud. Quellentexte zur Traumpsychologie im späten 19. Jahrhundert (Dreamwork before Freud; pp. 25-95). Gießen, Germany: Psychosozial-Verlag. (Original work published 1868)

van Hasselt, A. W. M. (1862). Die Lehre vom Tode und Scheintode [Science of death and apparent death]. Braunschweig, Germany: Verlag Friedrich Vieweg und Sohn.

Vogt, C., \& Vogt, O. (1922). Erkrankungen der Großhirnrinde im Lichte der Topistik, Pathoklise und Pathoarchitektonik [Diseases of cerebral cortex with regards to topistic, pathoclisis, and pathoarchitectonic]. In Journal für Psychologie und Neurologie, Bd. 28. Leipzig, Germany: Verlag von Johann Ambrosius Barth.

Volkelt, J. (2005). Die Traum-Phantasie [Dream fantasy]. In S. Goldmann (Ed.), Traumarbeit vor Freud. Quellentexte zur Traumpsychologie im späten 19. Jahrhundert (Dreamwork before Freud; pp. 97-240). Gießen, Germany: Psychosozial-Verlag. (Original work published 1875)

von Schubert, G. H. (1814). Die Symbolik des Traumes [Symbolism of dreams]. Bamberg, Germany: Im neuen Leseinstitut von C. F. Kunz.

Wagner-Jauregg, J. (1889). Ueber einige Erscheinungen im Bereiche des Centralnervensystems, welche nach Wiederbelebung Erhängter beobachtet wer- 
den [About some occurrences of the central nervous system which were observed after reanimation of strangulated persons]. Jahrbücher für Psychiatrie, 8, 313-332.

Wagner-Jauregg, J. (1893). Noch ein Wort über Krämpfe und Amnesie nach Wiederbelebung Erhängter. Eine Erwiderung an P. J. Möbius [One more word about cramps and amnesia after reanimation of strangulated persons. A response to P. J. Möbius]. Münchner Medicinische Wochenschrift, 40, 194. 